\title{
Distinctive Characteristics of Educational Donors
}

Received (in revised form): September 22, 2007

\section{Russell N. James III}

is an assistant professor at the University of Georgia in the Department of Housing \& Consumer Economics. Previously, Dr. James served for six years as the director of planned giving and for six years as college president at Central Christian College in Moberly, Missouri.

\begin{abstract}
Examining the charitable behavior of 56,663 US households, this paper evaluates the distinctive characteristics of educational donors as compared with donors to noneducational charitable organizations and with nondonors. In general, educational donors had significantly greater income, wealth, and education than other donors. Educational donors were broadly generous, giving more to religious charities, as well as noneducational and other charities than did other donors. Probit and Tobit regression analyses revealed that an individual's educational level was the strongest predictor of charitable donations to education institutions. Educational attainment was also more strongly associated with educational giving than with other types of charitable giving.
\end{abstract}

\footnotetext{
Author's Contact Address:

Russell N. James III

Consumer Research Center (House C)

203415 Sanford Dr. University of Georgia

Athens, GA 30602, USA

Phone: +1 7065424951

Fax: +1 7065830313

Email: rjames@fcs.uga.edu
}

\author{
International Journal of Educational \\ Advancement (2008) 8, 3-12. \\ doi:10.1057/ijea.2008.1
}

\section{Keywords:}

charitable giving, philanthropy, demographics, fund raising, consumer expenditure survey, donors

\section{Introduction}

Much of the empirical research related to giving to institutes of higher education has come from analyses of the experience of individual educational institutions or groups of institutions. At the same time, economic analysis of household-level charitable giving from nationally representative data sets has tended to group all forms of charitable giving together into a single summative category. Thus, the information on educational charitable giving is often limited either to institution-specific samples or to presumed analogies drawn from general charitable giving practices. This study attempts to bridge this divide by using a nationally representative data set on household expenditures to analyze educational giving. This provides an opportunity to 
examine how educational donors differ from other charitable donors, and thus to consider the validity of applying general charitable giving findings to the specific field of educational giving.

A common approach in nationally representative studies of household charitable giving is to treat all charitable giving as a single category. For example, studies based upon tax return data must necessarily treat all forms of deductible charitable giving identically because tax deduction data amalgamates religious, educational, and other charitable gifts (Randolph, 1995). Other national surveys, such as the Survey of Consumer Finances, similarly combine charitable giving information into a single category. Even where it has been possible, past studies have generally not examined educational giving separately from other forms of charitable giving. One previous study using the Consumer Expenditure Survey looked at charitable gifts to relief organizations, and excluded religious charitable gifting, charitable gifts to educational institutions, and miscellaneous charitable gifts as being "questionable" classes of contributions (Reece, 1979). When studies have separately examined different charitable giving categories, the most common division has been between religious and nonreligious charitable giving, largely due to the potential for differing price and income elasticities (Clotfelter, 1985).

Studies of household charitable giving have revealed consistent relationships between giving and basic socio-economic characteristics. Charitable giving is positively associated with greater levels of income (James and Sharpe, 2007), wealth (Andreoni and Scholz, 1998), and education (Brown and Lankford, 1992; Feldstein and Clotfelter, 1976; Kingma, 1989). However, none of these studies have examined to what extent these characteristics are more or less effective in predicting educational giving as compared with other forms of charitable giving.

For studies specific to educational giving, research has mostly been restricted to studies of the experiences of particular educational institutions or groups of institutions. So, for example, Weerts and Ronca (2007) examine records from a single university, Harbaugh (1998) examines a small group of donors to a particular law school, and Glazer and Konrad (1996) consider records from a unit at Carnegie Mellon University.

This paper adds to the existing literature by using a nationally representative data set of household expenditures to examine educational giving. This provides a useful point of comparison with previous national studies where educational giving was subsumed under a general "charitable giving category" and with previous institution-specific studies of educational giving experiences.

\section{Data (Sample)}

Data for this study come from the Consumer Expenditure Survey (CES) produced by the US Bureau of Labor Statistics. The CES is a widely used source of data for economic research and analysis. Among other things, the CES is used in revising the Consumer Price Index. The focus of the CES is to provide a "continuous and comprehensive flow of data on the buying habits of American consumers" (Bureau of Labor Statistics, 2006, p. 6). By using an interview process, 
the CES collects data on up to 95 percent of household expenditures. The sample used for this research is drawn from the detailed income and expenditure data collected during the ten years from the second quarter of 1995 through the first quarter of 2005. This extended period of collection insures a representation of a variety of economic conditions. Given that only about 6.6 percent of the interviewed households reported educational charitable giving, the extended period of collection also helps to insure a large sample size of educational donors.

The CES is a rotating panel survey. Households report expenditures in the CES for five consecutive quarters and then drop from the survey. Thus, each quarter 20 percent of the sample drops out and is replaced by new households. For surveys prior to the second quarter of 2001, households reported charitable giving information only in their final, fifth quarterly interview. In order to treat each year consistently and to avoid duplicate observations of the same households, we limit the sample in all years to those households making their fifth quarterly report. Because each household completes only one fifth quarter interview, no household is represented more than once in the sample. To eliminate those households refusing to report critical income information, the sample includes only those households classified as complete income reporters. This results in a sample of 56,663 unique households.

\section{Data (Variables)}

From 1995 through the first quarter of 2001, educational giving information resulted from answers to the following question asked in the final interview, "During the past 12 months, how much were contributions to educational organizations made by you (or any members of your [household])?" Other charitable contributions include answers to the following questions:

During the past 12 months, how much were contributions to church or other religious organizations, excluding parochial school expenses, made by you (or any members of your [household])?

During the past 12 months, how much were contributions to charities, such as United Way, Red Cross, etc., made by you (or any members of your [household])? During the past 12 months, how much were other contributions made by you (or any members of your [household])?

Beginning in 2001, charitable giving information was collected every quarter. For these households, charitable giving amounts come from summing the amounts reported in the final four quarters generated by the following questions:

Since the 1st of (month, 3 months ago), have you (or any members of your [household]) given any money by cash, checks, money orders, or credit cards to benefit(1) Educational institutions (2) Religious organizations, including churches, temples, and mosques, but not including parochial schools (3) Charities and all other organizations

Independent variables used in this analysis include broad scope economic 
and sociodemographic factors such as income before taxes, liquid assets, homeownership, reference person's education, race and marital status, presence of minor children in the household, and urban or rural location. The reference person is the first member mentioned by the respondent when asked to "start with the name of the person or one of the persons who owns or rents the home" (Bureau of Labor Statistics, 2006, p. 99).

All dollar figures are given in constant 2005 dollars, adjusted by the Consumer Price Index. Before-tax income includes all sources of reported income such as wages, government transfers, interest, capital gains, and the like for the previous 12 months. Liquid assets include all household checking accounts, savings accounts, brokerage accounts and stocks, mutual funds, private bonds, government bonds, or Treasury notes. Some financial variables used in the CES are topcoded (replaced with a value representing the mean of the subset of all observations above a certain critical level) in order to preserve respondent confidentiality.

The analysis also collapses marital status categories into three groups: married, single male, and single female. All nonmarried categories (e.g., never married, divorced, and widowed) are included in the single designation. The urban status variable is 1 if the household is located in a town of 2,500 or more persons, and zero otherwise. The educational level of "some college" includes those with any amount of college education less than a full bachelor's degree. The "graduate degree" designation includes those with any graduate or professional degree beyond the bachelor's degree.

\section{Descriptive Analysis}

Table 1 reports descriptive characteristics for all sample households, for donors who did not give to educational organizations, and for donors who did give to educational organizations. As a group, educational donors had dramatically higher markers of socio-economic status than other donors. Educational donors had over 50 percent more income and over two and one-half times more liquid wealth than other donors did.

Educational donors were also significantly more likely to own their home. Educational donors out-gave other kinds of charitable donors, giving more than twice as much overall as other charitable donors and giving almost three and one-half times more to religious organizations. The connection between educational donors and religious giving is seen not only in average giving levels, but also in the frequency of participation. Though not reported in the Table 1 , over two-thirds (66.1 percent) of educational donors gave to religious organizations. This compares with 57.3 percent of donors to other nonreligious organizations and 39.2 percent of the sample as a whole who gave to religious organizations.

Educational donors were significantly more likely to be married and to have minor children in the home than other types of donors were. Correspondingly, educational donor households were less likely to include retirement-aged individuals. These descriptive statistics suggest the presence of a natural connection between educational giving and children. As the recipients of educational benefits are often children or young adults, it is not surprising to see educational donors more 
Table 1: Descriptive statistics 1995-2005 consumer expenditure survey mean (standard deviation)

\begin{tabular}{|c|c|c|c|}
\hline Variable & All households & Noneducational donors & Educational donors \\
\hline$N$ & 56,663 & 27,074 & 3,774 \\
\hline Income & $52,486.88(50,581.01)$ & $58,536.93(51,736.54)$ & $90,027.37 *(72,067.74)$ \\
\hline Liquid assets & $33,458.21$ & $41,068.40$ & $116,837.74 *$ \\
\hline & $(173,147.62)$ & $(189,771.13)$ & $(353,392.81)$ \\
\hline All charitable giving & $760.86(4,010.74)$ & $1,180.54(3,220.39)$ & $2,954.59 *(12,534.81)$ \\
\hline Religious giving & $152.67(2,078.29)$ & $215.66(1,740.62)$ & $745.14 *(6,525.87)$ \\
\hline Relief giving & $563.95(2,236.66)$ & $952.27(2,435.85)$ & $1,635.84 *(5,305.35)$ \\
\hline Miscellaneous giving & $8.06(250.80)$ & $12.61(323.05)$ & $30.48(441.25)$ \\
\hline Age & $48.4(17.6)$ & $51.2(17.3)$ & $50.9(15.2)$ \\
\hline Family size & $2.54(1.51)$ & $2.58(1.48)$ & $2.7(1.42)$ \\
\hline Married (\%) & 53.8 & 60.9 & $70.1^{*}$ \\
\hline Single male $(\%)$ & 17.5 & 12.9 & $10.6^{*}$ \\
\hline Single female (\%) & 28.7 & 26.2 & $19.4^{*}$ \\
\hline$<$ High school $(\%)$ & 16.1 & 12.9 & $3.0 *$ \\
\hline HS graduate (\%) & 28.5 & 27.5 & $12.0^{*}$ \\
\hline Some college $(\%)$ & 29.0 & 30.7 & $20.8^{*}$ \\
\hline Bachelor's degree $(\%)$ & 17.1 & 18.9 & $33.4 *$ \\
\hline Graduate degree (\%) & 9.3 & 9.9 & $30.7^{*}$ \\
\hline Black (\%) & 11.0 & 10.1 & $5.0 *$ \\
\hline White (\%) & 83.7 & 84.8 & $90.2 *$ \\
\hline $\operatorname{Urban}(\%)$ & 90.5 & 90.6 & 91.4 \\
\hline Household w/persons over $64(\%)$ & 23.7 & 28.1 & $22.7 *$ \\
\hline Household w/children under $18(\%)$ & 36.2 & 35.0 & $38.8 *$ \\
\hline Homeowner $(\%)$ & 63.8 & 73.5 & $83.3 *$ \\
\hline Renter (\%) & 33.2 & 23.9 & $14.4^{*}$ \\
\hline
\end{tabular}

"Indicates difference from noneducational donors is significant at $p<0.01$

Sample includes complete income reporters making a fifth quarter report from the second quarter of 1995 through the first quarter of 2005

frequently including married families with children.

While the differences in many of the categories are significant, the differences in educational attainment are particularly dramatic. More than three times as many educational donors have completed a graduate degree as compared with other donors or the sample as a whole. While only about one quarter of the reference persons from the entire sample had completed at least a bachelor's degree, almost two-thirds of educational donors had done so. Thus, donors to education institutions appear to be most typically those who have received the benefits of higher education.
Figure 1 further demonstrates the extent of this relationship. Where Table 1 reports the educational attainment of educational donors, Figure 1 shows the charitable participation of households with various educational characteristics. As demonstrated by Figure 1, the likelihood of participating in charitable giving to educational organizations varies dramatically with educational attainment. An individual with education beyond the bachelor's degree is ten times more likely give to an educational organization than is an individual without any college education. 


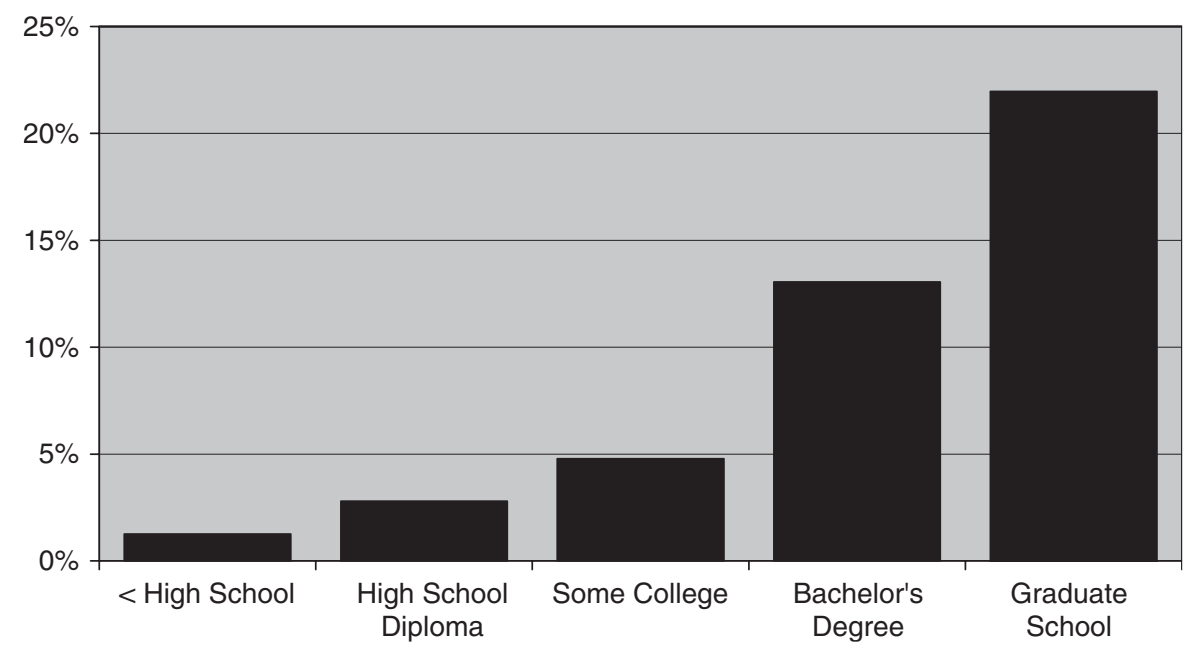

Figure 1: Proportion of households giving to education by respondent's education level

\section{Regression Models}

While the descriptive statistics give a good indication of the importance of various factors in predicting educational giving, multivariate regression models allow us to consider the separate impact of individual characteristics. For example, the impact of educational attainment may simply be the result of increased household income, rather than an independent effect of education. To allow for a separate examination of educational giving participation and educational giving levels, this paper employs two regression approaches. First, a probit analysis considers the impact of various factors on the likelihood of participating in educational charitable giving. Secondly, a Tobit analysis considers the association of those same factors with the predicted level of educational giving.

\section{Probit analysis}

The probit analysis estimates the impact of each independent variable on the likelihood that a household would have made a charitable gift to an educational organization during the previous 12 months. Table 1 reports the coefficient estimates and standard errors for each independent variable. These coefficient estimates indicate the significance and relative size of the impact of each independent variable on the likelihood of a household's participation in educational giving. However, these coefficients do not correspond directly to predicted probabilities. Estimating the predicted probability for a particular household requires first multiplying the numerical value of each characteristic by each coefficient. The sum of these products plus the intercept represents a point on the standard normal distribution, which corresponds to a predicted probability. To aid in the interpretation of these coefficients, the second column of Table 2 reports the estimated probability change. This probability change is the percentage point change in the estimated probability of making 
Table 2: Regressions on likelihood and amount of educational gifting coefficient (standard error)

\begin{tabular}{|c|c|c|c|}
\hline & $\begin{array}{l}\text { Probit on presence of } \\
\text { educational giving }\end{array}$ & $\begin{array}{l}\text { Probability } \\
\text { change }\end{array}$ & $\begin{array}{l}\text { Tobit on educational } \\
\text { giving } \$ \text { amount }\end{array}$ \\
\hline Income ( $\$ 10,000$ units $)$ & $0.0230 * *(0.0016)$ & 0.22 & $110.49 * *(6.84)$ \\
\hline Liquid assets ( $\$ 10,000$ units) & $0.0028 * *(0.0003)$ & 0.03 & $10.95 * * *(1.40)$ \\
\hline Homeowner & $0.2156 * *(0.0241)$ & 1.89 & $810.76 * *(108.00)$ \\
\hline Age & $0.0073 * *(0.0007)$ & 0.07 & $32.60 * * *(2.96)$ \\
\hline White & $0.1294 * *(0.0279)$ & 1.11 & $511.00 * * *(124.91)$ \\
\hline Household w/children under 18 & $0.0949 * * *(0.0217)$ & 0.89 & $312.15 * *(96.22)$ \\
\hline Single male & $-0.1434 * * *(0.0297)$ & -1.10 & $-497.78 * * *(131.87)$ \\
\hline Single female & $-0.0543 *(0.0237)$ & -0.27 & $-126.13(105.36)$ \\
\hline Urban & $-0.0817 * *(0.0313)$ & -0.80 & $-449.55 * *(138.00)$ \\
\hline$<$ High school & $-0.2993 * * *(0.0424)$ & -1.30 & $-1229.85 * * *(191.59)$ \\
\hline Some college & $0.2738 * *(0.0272)$ & 2.08 & $1147.54 * * *(123.00)$ \\
\hline Bachelor graduate & $0.7389 * *(0.0274)$ & 8.58 & $2937.96 * *(127.03)$ \\
\hline Graduate degree & $0.9880 * * *(0.0298)$ & 14.02 & $3845.97 * * *(138.96)$ \\
\hline Intercept & $-2.692 * * *(0.0765)$ & & $-12000.60 * *(367.35)$ \\
\hline$N$ & 56,663 & & 56,663 \\
\hline
\end{tabular}

Notes: $* p<0.05, * p<0.01, * * p<0.001$

The probit model reflects the likelihood of making educational gifts

The probability change indicates the percentage point change in the estimated probability of making an educational gift in the presence of the variable (as compared to its absence) or, for age, income, and assets, in the presence of a one unit increase in the variable (as compared to the variable's sample mean) assuming the individual otherwise has sample mean characteristics

The Tobit model estimates the combined impact of each variable on both the likelihood and level of educational giving

Year dummy variables are included but not reported for all models

an educational gift associated with an independent variable, where the individual had average characteristics for all other variables. For variables reflecting the presence or absence of a characteristic, the number reflects the estimated probability change resulting from the presence of the characteristic as compared with the presence of the comparison variable (e.g., urban versus rural). For continuous variables, the number reflects the estimated probability change resulting from a one-unit increase in the variable from variable's sample mean. Because generating predicted probabilities requires inserting values for all independent variables, this analysis uses sample mean characteristics for all other variables not under examination.

So, for example, in a household with sample mean characteristics, increasing income by $\$ 10,000$ increases the estimated probability of making a gift to education by 0.22 percentage points. Similarly, in a household with sample mean characteristics for all other variables, homeownership is associated with a 1.89 percentage point increase in the likelihood of educational gifting as compared with renting. It is important to keep in mind that the predicted probability change resulting from the presence of a binary variable is the change in probability as compared with the base or comparison case. In examining the 
reference person's educational attainment, the base or comparison case is that of a high school graduate. Thus, a household with otherwise sample mean characteristics with a reference person having less than a high school diploma is 1.3 percentage points less likely to make an educational gift than one with only a high school diploma. The predicted giving probability associated with educational attainment of the reference person demonstrates the dramatic impact of educational attainment on educational giving. Increasing the income of a household with sample mean characteristics even by $\$ 100,000$ does not improve the probability of making educational gifts by as much as changing the reference person's educational level from a high school graduate to a bachelor's degree graduate. The probit results clearly demonstrate that the single most dominant factor associated with the presence of educational giving is the household's educational attainment, even when holding associated factors such as income and wealth constant.

\section{Tobit analysis}

The Tobit analysis combines considerations of both giving likelihood and giving level to estimate the association of various factors with predicted giving amounts. Because of the high frequency of $\$ 0$ observations in our dependent variable (i.e., households with $\$ 0$ of educational giving), an ordinary least squares approach is not well suited for this analysis. In this sample, only about six and one-half percent of all households made gifts to educational organizations. This creates a problem for the ordinary least squares approach because the residuals (error terms) for over 93 percent of the observations will be the negative of the predicted value, thus creating problems for the assumptions of homoskedasticity and normality of the residuals. Consequently, the final analysis uses a Tobit approach where we restore the assumption of normality in residuals by estimating an equation where results are "truncated" at zero, but represent an underlying equation where there are various degrees of intended giving falling below zero.

Much like the results of the probit analysis, the Tobit model demonstrates the importance of a range of variables in predicting educational giving, but once again shows the overwhelming importance of the reference person's educational level. As is commonly found with other forms of charitable giving, factors such as wealth, income, age, and marriage are all positively associated with educational giving.

\section{Comparing giving types}

Clearly, the impact of education levels on educational giving is a dominant factor. But, is education more important to educational giving than it is to other forms of charitable giving? As might be expected from the descriptive statistics, the answer appears to be yes. To test the answer to this question, Table 3 reports measurements of the association between a particular level of education and three different types of giving: educational, religious, and other charitable giving. In all cases, the 
Table 3: Probit comparing associations of education with different types of giving coefficient (95 percent confidence interval)

\begin{tabular}{llll}
\hline Dependent variable & \multicolumn{2}{l}{ Independent variables } & \\
\cline { 2 - 4 } & $\begin{array}{l}\text { Presence of educational } \\
\text { giving }\end{array}$ & $\begin{array}{l}\text { Presence of religious } \\
\text { giving }\end{array}$ & $\begin{array}{l}\text { Presence of other } \\
\text { charitable giving }\end{array}$ \\
\hline Graduate degree & 0.610 & 0.061 & 0.188 \\
Bachelor's degree & $(0.658,0.561)$ & $(0.094,0.028)$ & $(0.222,0.154)$ \\
Some college & 0.336 & 0.132 & 0.182 \\
High school & $(0.382,0.290)$ & $(0.160,0.105)$ & $(0.210,0.153)$ \\
< High school & -0.258 & 0.105 & 0.104 \\
& $(-0.210,-0.307)$ & $(0.129,0.081)$ & $-0.129,0.078)$ \\
& -0.487 & -0.097 & $(-0.034,-0.087)$ \\
& $(-0.431,-0.543)$ & $-0.073,-0.122)$ & -0.336 \\
\hline
\end{tabular}

Note: Independent variables included but not reported are income $(\$ 10,000$ units), liquid assets $(\$ 10,000$ units), homeowner, age, white racial status, household w/children under 18, single male, single female, urban, intercept, and individual year dummy variables

models included controls for the same set of socio-economic variables as in the previous models. (To produce most conveniently comparable coefficients, we use the presence of the education level as the left-hand-side variable and the three types of giving as right-handside variables in the probit regressions in Table 3.)

As can be observed in Table 3, the magnitude of the association between educational giving and the individual's education level is generally far greater than is the association between other forms of giving and the individual's education level. For both higher and lower levels of education, the 95 percent confidence intervals for educational giving and other forms of giving do not cross, indicating a statistically significant difference in the magnitudes of association. While higher educational attainment is associated with a greater likelihood of giving for every form of charitable giving, its association with educational giving is of a significantly greater magnitude than its association with other forms of giving.

\section{Summary}

How do educational donors differ from other donors? Educational donors have greater wealth, income, education, and are more likely to be of majority racial status, have children and be married. Along with having greater economic power, educational donors are broadly generous. In addition to giving to education, educational donors give more to religion and other charitable organizations than do other types of donors. Thus, educational donors appear to have diverse charitable interests. Educational donors are not "silo donors" focused on a single organization or single type of charitable category. This suggests, among other things, that educational donors will likely be contacted regularly by a variety of different 
charitable organizations. Consequently, educational advancement personnel must stay competitive with overall fund-raising industry practices in order to be successful.

As demonstrated by these results, education tends to replicate itself through educational giving. Those who have committed significant portions of their adult lives to higher education are much more likely to support financially the provision of educational opportunity to others. While increased education improves the likelihood and level of all forms of charitable giving, it most strongly improves the likelihood and level of educational giving. Advancement professionals are often concerned with targeting prospective donors who are not currently giving to their organization. While this study indicates that it is possible to target potential educational donors by identifying those with a range of privileged socio-economic characteristics, the dominant characteristic predicting educational giving is the individual's educational attainment. As Figure 1 demonstrates, knowing only this one characteristic can tell us if the individual is in a category where 22 percent give to education (graduate degree), or in a category where only 1 percent give to education (no high school diploma). Although a prospect's educational attainment is a useful predictor for development personnel in any area of charitable giving, it is a significantly more important predictor for those in educational advancement. Thus, to a greater extent than in other areas of charitable development, educational advancement professionals would do well to employ prospecting techniques focused on the educational attainment of potential donors.

\section{References}

Andreoni, J. and Scholz, J. (1998), “An econometric analysis of charitable giving with interdependent preferences," Economic Inquiry, 36, pp. 410-428.

Brown, E. and Lankford, H. (1992), "Gifts of money and gifts of time: Estimating the effects of tax prices and available time," Journal of Public Economics, 47, pp. 321-341.

Bureau of Labor Statistics (2006), 2004 Consumer Expenditure Interview Survey Public Use Microdata Documentation, US Department of Labor, Washington, DC.

Clotfelter, C. (1985), Federal Tax Policy and Charitable Giving, The University of Chicago Press, Chicago.

Feldstein, M. and Clotfelter, C. (1976), “Tax incentives and charitable contributions in the United States," Journal of Public Economics, 5, pp. 1-26.

Glazer, A. and Konrad, K. (1996), "A signaling explanation for charity," The American Economic Review, 87, pp. 1019-1028.

Harbaugh, W. (1998), "What do donations buy? A model of philanthropy based on prestige and warm glow," Journal of Public Economics, 67, pp. 269-284.

James, R.N. III and Sharpe, D.L. (2007), "The nature and causes of the U-shaped charitable giving profile," Nonprofit and Voluntary Sector Quarterly, 36, 2, pp. 218-238.

Kingma, B. (1989), “An accurate measurement of the crowd-out effect, income effect and price effect for charitable contributions," Journal of Political Economy, 97, 5, pp. 1197-1207.

Randolph, W. (1995), "Dynamic income, progressive taxes, and the timing of charitable contributions," Journal of Political Economy, 103, 4, pp. 709-738.

Reece, W. (1979), “Charitable contributions: New evidence on household behavior," The American Economic Review, 89, 1, pp. 142-151.

Weerts, D.J. and Ronca, J.M. (2007), "Profiles of supportive alumni: Donors, volunteers, and those who 'do it all'," International Journal of Educational Advancement, 7, 1, pp. 20-34. 